\title{
Phytochemical characterization, and antioxidant and antimicrobial activities of essential oil from leaves of the common sage Salvia officinalis $L$. from Abha, Saudi Arabia
}

\author{
Atef El Jery ${ }^{1,2 * \odot}$, Mudassir Hasan ${ }^{1 \oplus}$, Md Mamoon Rashid ${ }^{1 \oplus}$, Mohammed Khaloofah Al Mesfer $^{1 \odot}$, \\ Mohd Danish $^{1 \oplus}$, Faouzi Ben Rebah ${ }^{3,4}$
}

\section{Abstract}

Background: The composition and activities of essential oil of common sage from Saudi Arabia have not yet been reported.

Objectives: To analyze the composition and antibacterial and antioxidant activities of essential oil from leaves of the common sage Salvia officinalis L. from Abha, Saudi Arabia.

Methods: Essential oil was extracted from the leaves of $S$. officinalis by hydrodistillation, and its composition was analyzed using gas chromatography and mass spectrometry. Phenolics and flavonoids were determined using gallic acid and quercetin standards. Antioxidant activity was determined using a 2,2-diphenyl-1-picrylhydrazyl radical scavenging method. Activity against various gram-positive and gram-negative bacteria was determined by disk diffusion and microdilution.

Results: The yield of essential oil was $3.24 \pm 0.55 \%$ (w/dry weight). Major compounds identified were camphor (20.3\%), 1,8-cineole (15.0\%), $\alpha$-thujone (14.9\%), viridiflorol (9.9\%), carvone (6.2\%), and $\beta$-thujone (5.7\%). Phenolic content was $134.3 \pm 17.61 \mu \mathrm{g} / \mathrm{mL}$ and flavonoid content was $119.5 \pm 18.75 \mu \mathrm{g} / \mathrm{mL}$. Antioxidant $\mathrm{IC}_{50}$ was $970 \pm 5.5 \mu \mathrm{g} /$ $\mathrm{mL}$. The highest gram-positive antibacterial activity was for Bacillus subtilis and the highest gram-negative activity was for Escherichia coli. Minimum inhibitory concentrations ranged from $62.2 \pm 3.9$ to $1398.1 \pm 50.7 \mu \mathrm{g} / \mathrm{mL}$ for grampositive bacteria and from $323.4 \pm 69.5$ to $968.4 \pm 120.6 \mu \mathrm{g} / \mathrm{mL}$ for gram-negative bacteria. Minimum bactericidal concentrations ranged from $120.3 \pm 7.6$ to $1387.4 \pm 161.8 \mu \mathrm{g} / \mathrm{mL}$ for gram-positive bacteria and from $386 \pm 8.3$ to $1225.2 \pm 100.9 \mu \mathrm{g} / \mathrm{mL}$ for gram-negative bacteria.

Conclusions: Essential oil of S. officinalis L. from Abha, Saudi Arabia, showed compositional, antioxidant, and antibacterial properties generally consistent with essential oil of $S$. officinalis L. from other locations as reported in the literature.

Keywords: microbial sensitivity tests; antioxidants; phytochemistry; oils, volatile; Salvia officinalis, Saudi Arabia

\footnotetext{
*Correspondence to: Atef El Jery, Department of Chemical Engineering, College of Engineering, King Khalid University, PO Box 394, Abha 61411, Saudi Arabia, e-mail: ajery@kku.edu.sa

'Department of Chemical Engineering, College of Engineering, King Khalid University, Abha 61411, Saudi Arabia

${ }^{2}$ Higher Institute of Applied Biology, Gabes University, Medenine 4119, Tunisia

${ }^{3}$ Department of Chemistry, College of Science, King Khalid University, Abha 61413, Saudi Arabia

${ }^{4}$ Higher Institute of Biotechnology of Sfax, Sfax University, Sfax 3000, Tunisia
}

¿ Open Access. ๑ 2020 El Jery et al., published by Sciendo. (c))BY-Nc-ND This work is licensed under the Creative Commons Attribution NonCommercial-NoDerivatives 4.0 License. 
In various countries, the demand for medicinal and aromatic plants is increasing because of their use in many fields, including medicine, nutrition, beverages, insect repellents, perfumes, flavors, cosmetics, and dyeing [1]. The diversity of these plants and their indispensable use as a source of raw materials as natural products potentially has considerable economic benefits. Various secondary metabolites are produced by these plants. Among these metabolites, volatile molecules with olfactory activity and high added value comprise essential oils [2].

The common sage (Salvia officinalis L.), belonging to the Lamiaceae family [3], is considered a medicinal and culinary herb and is widely used either in its natural state or in the form of extracts or essential oil. Besides its traditional use in common food and folk medicine, sage contains many substances having various interesting properties [4]. Sage has effects on human health through the biological properties of its components, such as anti-inflammatory, antibacterial, fungistatic, virostatic, astringent, eupeptic, and antihydrotic properties [4, 5]. These have potential applications in the pharmaceutical and medicinal sectors, such as in the management of Alzheimer disease [6], and from their hypoglycemic and antimutagenic activities [7]. Sage is integrated as an active ingredient in a mixture of plant preparations and it is useful for the treatment of bronchitis [8].

Essential oils are commonly used in the pharmaceutical industry, cosmetics, perfumery, food processing, and aromatherapy [8]. The essential oils of sage are complex mixtures of various active ingredients. Moreover, the reported medicinal properties (including antiseptic, antispasmodic, soothing, cephalic, digestive, and febrifuge activities) of sage essential oil make this plant valuable [9]. The chemical composition of essential oil from sage grown in many regions worldwide has been studied (including Tunisia, Greece, Algeria, Serbia, Montenegro, Iran, Kashmir, Turkey, and Croatia) [10-17]. These studies found variability in the chemical composition and biological properties of sage essential oil. Generally, characteristics of sage essential oil depend on various factors, such as the location, the season, abiotic factors (including temperature, sunlight, humidity, acidity, and soil), and the extraction procedure. The importance of these factors has stimulated the investigation of the chemical composition and the biological activities of essential oil of sage harvested in various locations worldwide [18]. Saudi Arabia is among the attractive countries for sage production and is characterized by substantial plant diversity; however, all data for sage are from plant origins other than in Saudi Arabia. Our research was in part motivated by the economic and environmental concerns related to medicinal plants from Saudi Arabia, which could make important contributions to the conception of new uses for natural products. Because the essential oil composition of sage varies, based on different factors including the geographical location of plant growth, the purpose of the present study was to investigate the phytochemical characterization and the biological activities of the essential oil of the leaves of the common sage, S. officinalis L., collected from the Abha region in Saudi Arabia.

\section{Methods}

\section{Plant material}

Leaves of $S$. officinalis L. were sampled from natural populations situated in Abha (southern region of Saudi Arabia; latitude: $18^{\circ} 13^{\prime} 0.4692^{\prime \prime} \mathrm{N}$, longitude: $42^{\circ} 30^{\prime} 19.01^{\prime \prime} \mathrm{E}$, altitude: $2,400 \mathrm{~m}$ ) in winter-spring 2018. The plant is not considered an endangered or protected species, and no specific permit was required for its collection. Plants were identified by Professor Wissem Mnif (Faculty of Sciences and Arts in Balgarn, University of Bisha, Saudi Arabia), and voucher specimens (SO1) have been deposited in the Higher Institute of Applied Biology of Medenine (Tunisia). Samples were dried in the shade while ventilated at room temperature for 15 days. A disc mill machine (model FFC-45; Zhengzhou Kaishan Mechanical \& Electrical Equipment Co., China) was used for decortication of the stem-free leaf samples.

\section{Essential oil extraction}

The essential oil was extracted from the air-dried leaves $(200 \mathrm{~g})$ by hydrodistillation using a Clevenger-type apparatus $(4 \mathrm{~h})$. Petroleum ether was used to extract the aqueous phase $(3 \times 50 \mathrm{~mL})$, then dried with anhydrous sodium sulfate. After filtration, the petroleum ether was removed using a rotary evaporator (model 94200; Heidolph Instruments, Germany) under reduced pressure to ensure its complete removal. Samples were stored in amber glass bottles (at $4{ }^{\circ} \mathrm{C}$ ) until use [18]. The extracted oil was weighed to determine the yield as estimated based on the dry weight of the plant material.

\section{Gas chromatography-mass spectrometry analysis}

The composition of the essential oil from leaves of Salvia officinalis L. was determined using a Hewlett Packard HP 5890 gas chromatography system coupled with an HP 5972 Mass Selective Detector (Agilent Technologies), set to scan from 
$20 \mathrm{~m} / \mathrm{z}$ to $550 \mathrm{~m} / \mathrm{z}$. The gas chromatography-mass spectrometry (GC-MS) analysis was conducted using a DB-5 capillary column (length $25 \mathrm{~m}$, internal diameter $0.25 \mathrm{~mm}$, and $0.25 \mu \mathrm{m}$ film thickness; Agilent Technologies). The carrier gas was helium at a linear velocity (u) of $30.1 \mathrm{~cm} / \mathrm{s}$ with an inlet pressure of $99.8 \mathrm{kPa}$. The detector temperature was adjusted at 250 ${ }^{\circ} \mathrm{C}$ at a carrier gas flow rate of $1.2 \mathrm{~mL} / \mathrm{min}$. Feed oil with $1 \%$ hexane was injected in a split mode in a volume of $0.2 \mu \mathrm{L}$ at 240 ${ }^{\circ} \mathrm{C}$. The ionization energy was $70 \mathrm{eV}$. The GC-flame ionization detection (FID) peaks are indicative of various chemical constituents of the oil, which were recognized based on comparing their retention time and mass spectra with entries in the Wiley version 7.0 and National Institute of Standards and Technology 05 MS (NIST) spectral data libraries. The peak area normalization was applied to determine the component percentages [19]. The GC-MS method was validated under the supervision of the Tunisian Ministry of Research and Higher education. The precision and interassay variation were evaluated as $>97 \%$.

\section{Total phenols}

The essential oil phenol content was determined using a Folin-Ciocalteau reagent method as previously described [20]. In brief, the extracted essential oil was mixed with $10 \%$ Folin-Ciocalteau reagent in a ratio $(10 \mu \mathrm{L}: 750 \mu \mathrm{L})$ and further mixed with $20 \% \mathrm{Na}_{2} \mathrm{CO}_{3}$ solution. After $1 \mathrm{~h}$ of reaction at room temperature, the absorbance was determined at $765 \mathrm{~nm}$ with a spectrophotometer (Shimadzu). Gallic acid was used as a standard for the calibration curve, which is used to determine the total phenol content. Results are presented as $\mu \mathrm{g} / \mathrm{mL}$ of the gallic acid equivalent (GAE).

\section{Total flavonoids}

To determine the flavonoid content, the essential oil was diluted in ethanol in a ratio of $1: 10$. Then, $75 \mu \mathrm{L}$ of $5 \% \mathrm{NaOH}$ solution was added to $250 \mu \mathrm{L}$ of the diluted oil solution. After a few minutes of incubation, $150 \mu \mathrm{L}$ of $7 \% \mathrm{AlCl}_{3}$ solution was added to the mixture. After $1 \mathrm{~h}$ of incubation at room temperature, the absorbance was determined at $510 \mathrm{~nm}$ using a spectrophotometer (Shimadzu). The flavonoid content was determined using a calibration curve of quercetin as a standard. Results were presented as $\mu \mathrm{g} / \mathrm{mL}$ of the quercetin equivalent $(\mathrm{QE})[21]$.

\section{Antioxidant activity}

The essential oil antioxidant activity was determined using the 2,2'-diphenyl-1-picrylhydrazyl (DPPH) free radical scavenging method [22]. Essential oil was diluted to $1 \mathrm{~mL}$ with methanol (range between $0 \mu \mathrm{g} / \mathrm{mL}$ and $1,000 \mu \mathrm{g} / \mathrm{mL}$ ), and $0.25 \mathrm{~mL}$ of DPPH radical solution $(0.2 \mathrm{mM})$ was added [23]. The absorbance was determined at $517 \mathrm{~nm}$ using a spectrophotometer (Shimadzu). The antioxidant activity percentage was calculated as follows [18]:

$$
\text { Inhibition }(\%)=\left(\frac{\mathrm{OD}_{\text {Control }}-\mathrm{OD}_{\text {Sample }}}{\mathrm{OD}_{\text {Control }}}\right) \times 100 \text {, }
$$

where $\mathrm{OD}_{\text {Control }}$ is the absorbance of the control (DPPH solution plus methanol) and $\mathrm{OD}_{\text {Sample }}$ is the absorbance of the sample including DPPH plus the oil. The essential oil concentration that could scavenge $50 \%$ of DPPH $\left(\mathrm{IC}_{50}\right)$ was determined as specified by Shimada et al. [24].

\section{Antibacterial activity}

\section{Bacteria}

We used 5 gram-positive bacteria (Enterococcus faecalis ATCC 29212, Micrococcus luteus ATCC 4698, Salmonella enterica ATCC 35664, Bacillus subtilis ATCC 6633, and Staphylococcus aureus ATCC 29213) and 5 gram-negative bacteria (Escherichia coli ATCC 8739, Klebsiella pneumoniae ATCC 10031, Shigella sonnei ATCC 29930, Agrobacterium tumefaciens ATCC 23308, and Pseudomonas aeruginosa ATCC 9027). Strains were grown on tryptone-casein-soy agar plates and cultivated at $37^{\circ} \mathrm{C}$ for $24 \mathrm{~h}$. All strains were obtained from the Medical Faculty of Sfax (Tunisia) and were isolated as reported in the literature [25].

\section{Disk diffusion assay}

A disk diffusion assay was applied to determine the antibacterial activities of the essential oil. We spread $100 \mu \mathrm{L}$ of bacterial suspension $\left(10^{8}\right.$ colony-forming units $\left.(\mathrm{CFU}) / \mathrm{mL}\right)$ on trypticase soy agar contained in Petri plates. We individually impregnated $6 \mathrm{~mm}$ diameter paper disks (Sigma Aldrich) with $50 \mu \mathrm{L}$ of the essential oil and placed the impregnated disks on the agar plate previously inoculated with the selected bacterial strain. Gentamicin ( $10 \mu \mathrm{g} / \mathrm{disk})$ was used as a positive control. As a negative antibacterial control, a disk soaked in hexane was used. After incubating the plates with the disks for $1 \mathrm{~h}$ at $4{ }^{\circ} \mathrm{C}$, they were then incubated at $37{ }^{\circ} \mathrm{C}$ for $24 \mathrm{~h}$. For each bacterial strain, the antibacterial activity was evaluated by measuring the diameter (in millimeters) of the growthinhibition zone [26]. 


\section{Minimum inhibitory concentration and minimum bactericidal concentration}

The minimum inhibitory concentration (MIC) and minimum bactericidal concentration (MBC) for the essential oil were determined using an agar dilution method [27].

\section{Statistical analyses}

Experiments were conducted in triplicate, and results are presented as means \pm standard deviation. The results were compared only for the antibacterial activity of the essential oil against various strains. Comparisons of means between groups were assessed using a one-way analysis of variance (ANOVA) with XLSTAT (version 10). Differences were considered significant at $P<0.05$.

\section{Results}

\section{Chemical composition of essential oil from leaves of}

\section{S. officinalis L.}

A yield of $3.24 \pm 0.55 \%$ (weight/dry weight) of essential oil, with a colorless or yellowish color and a characteristic spicy odor, was obtained by extraction from $S$. officinalis leaves using hydrodistillation. The percentages and the retention times (RI) of the identified compounds of the essential oil are shown in Figure 1 and summarized in Table 1. A total of 26 constituents, representing $99.92 \%$ of the total oil, were identified. The essential oil was dominated by the oxygenated monoterpenoids representing a fraction of $67.36 \%$. This fraction was composed of mainly camphor (20.3\%), 1,8-cineole (15.01\%), and $\alpha$-thujone, with a lesser

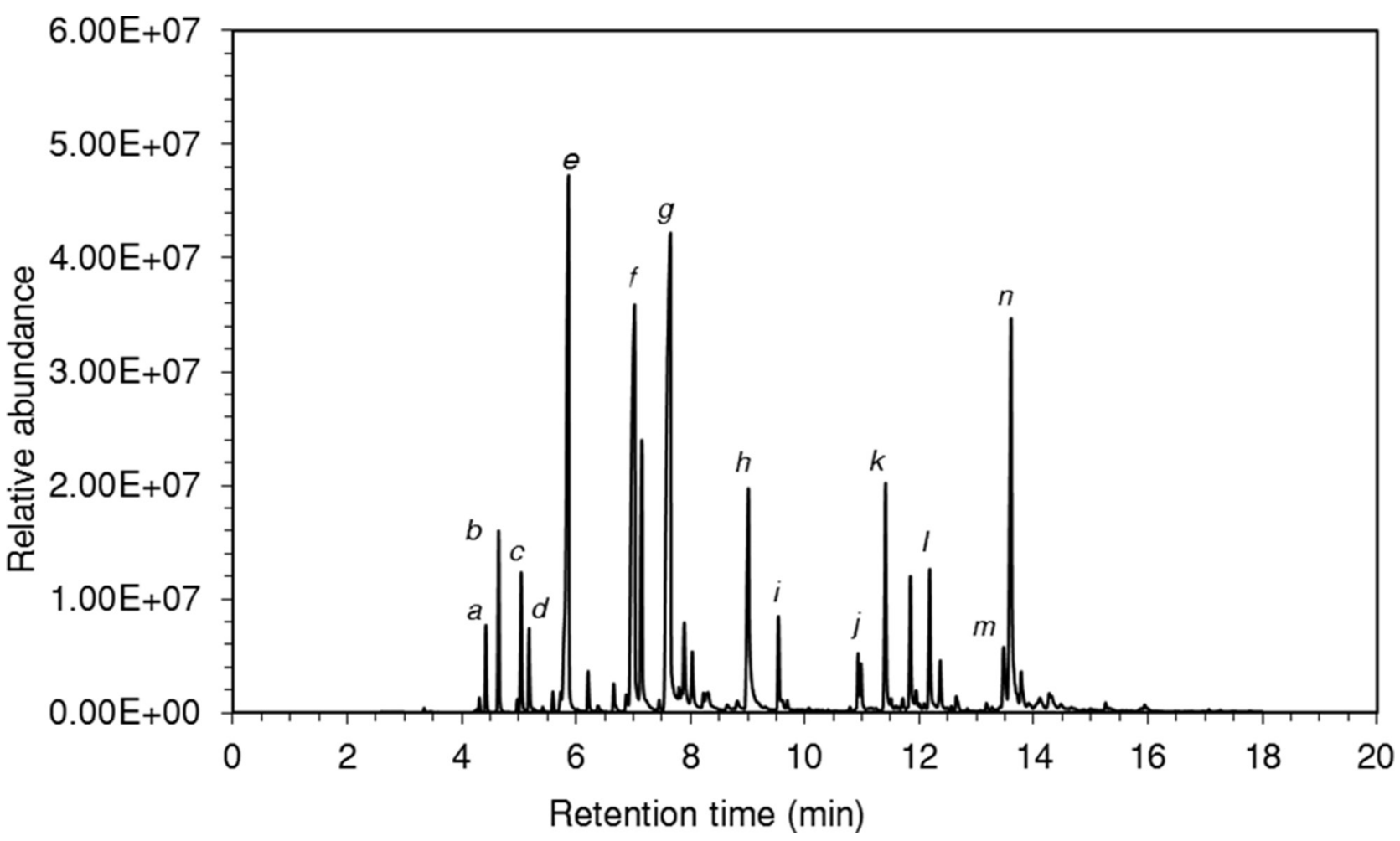

Figure 1. Gas chromatogram of essential oil from leaves of Salvia officinalis L. A Hewlett Packard HP 5890 gas chromatography system coupled with an HP 5972 Mass Selective Detector set to scan from 20 m/z to $550 \mathrm{~m} / \mathrm{z}$ was used with a DB- 5 capillary column (length 25 m; Agilent Technologies). The carrier gas was helium at a linear velocity of $30.1 \mathrm{~cm} / \mathrm{s}$ and an inlet pressure of $99.8 \mathrm{kPa}$. The detector temperature was $250^{\circ} \mathrm{C}$ with a $1.2 \mathrm{~mL} / \mathrm{min}$ carrier gas flow rate. Feed oil with $1 \%$ hexane was injected in a split mode in $0.2 \mu \mathrm{L}$ at $240^{\circ} \mathrm{C}$. The ionization energy was $70 \mathrm{eV}$. The flame ionization detection peaks are indicative of various constituents of the essential oil that were recognized by comparing their retention time and mass spectra with entries in the Wiley version 7.0 and National Institute of Standards and Technology 05 MS (NIST) spectral data libraries. Relative abundance and retention times are shown for the following: (a) $\alpha$-pinene; (b) camphene; (c) $\beta$-pinene; $(d)$ myrcene; (e) 1,8cineole; $(f) \alpha$-thujone; $(g)$ camphor; $(h)$ carvone; $(i)$ bornyl acetate; $(j) \beta$-bourbonene; $(k)$ trans- $\beta$-caryophyllene; $(l)$ germacrene $D ;(m)$, globulol; and (n) viridiflorol. 
Table 1. Composition of essential oil extracted from leaves of Salvia officinalis L. by hydrodistillation

\begin{tabular}{|c|c|c|c|c|}
\hline Volatile compoundt and chemical class & Retention time (min) & RIF & Percentage of total EO§ & Formula \\
\hline$\alpha$-Pinene & 4.42 & 938 & $1.15 \pm 0.1$ & $\mathrm{C}_{10} \mathrm{H}_{16}$ \\
\hline Camphene & 4.64 & 954 & $2.58 \pm 0.17$ & $\mathrm{C}_{10} \mathrm{H}_{16}$ \\
\hline$\beta$-Pinene & 5.04 & 980 & $2.06 \pm 0.05$ & $\mathrm{C}_{10} \mathrm{H}_{16}$ \\
\hline Myrcene & 5.18 & 994 & $1.26 \pm 0.11$ & $\mathrm{C}_{10} \mathrm{H}_{16}$ \\
\hline$\alpha$-Terpinene & 5.59 & 1,018 & $0.32 \pm 0.03$ & $\mathrm{C}_{10} \mathrm{H}_{16}$ \\
\hline p-Cymene & 5.73 & 1,026 & $0.36 \pm 0.02$ & $\mathrm{C}_{10} \mathrm{H}_{14}$ \\
\hline$\gamma$-Terpinene & 6.21 & 1,062 & $0.59 \pm 0.05$ & $\mathrm{C}_{10} \mathrm{H}_{16}$ \\
\hline$\alpha$-Terpinolene & 6.66 & 1,090 & $0.53 \pm 0.04$ & $\mathrm{C}_{10} \mathrm{H}_{16}$ \\
\hline Monoterpene hydrocarbons & & & 8.85 & \\
\hline 1,8-Cineole & 5.86 & 1,035 & $15.0 \pm 0.51$ & $\mathrm{C}_{10} \mathrm{H}_{18} \mathrm{O}$ \\
\hline$\alpha$-Thujone & 7.02 & 1,109 & $14.9 \pm 0.35$ & $\mathrm{C}_{10} \mathrm{H}_{16} \mathrm{O}$ \\
\hline$\beta$-Thujone & 7.15 & 1,120 & $5.7 \pm 0.27$ & $\mathrm{C}_{10} \mathrm{H}_{16} \mathrm{O}$ \\
\hline Camphor & 7.64 & 1,148 & $20.3 \pm 0.91$ & $\mathrm{C}_{10} \mathrm{H}_{16} \mathrm{O}$ \\
\hline Pinocamphone & 7.80 & 1,161 & $0.38 \pm 0.03$ & $\mathrm{C}_{10} \mathrm{H}_{10} \mathrm{O}$ \\
\hline Borneol & 7.89 & 1,168 & $2.16 \pm 0.14$ & $\mathrm{C}_{10} \mathrm{H}_{18} \mathrm{O}$ \\
\hline$\alpha$-Terpineol & 8.03 & 1,176 & $1.15 \pm 0.06$ & $\mathrm{C}_{10} \mathrm{H}_{18} \mathrm{O}$ \\
\hline Carvone & 9.01 & 1,248 & $6.2 \pm 0.15$ & $\mathrm{C}_{10} \mathrm{H}_{14} \mathrm{O}$ \\
\hline Bornyl acetate & 9.54 & 1,286 & $1.6 \pm 0.07$ & $\mathrm{C}_{12} \mathrm{H}_{20} \mathrm{O}_{2}$ \\
\hline Oxygenated monoterpenes & & & 67.36 & \\
\hline$\beta$-Bourbonene & 10.93 & 1,385 & $0.89 \pm 0.03$ & $\mathrm{C}_{15} \mathrm{H}_{24}$ \\
\hline$\beta$-Elemene & 10.98 & 1,391 & $0.82 \pm 0.03$ & $\mathrm{C}_{15} \mathrm{H}_{24}$ \\
\hline trans- $\beta$-Caryophyllene & 11.41 & 1,419 & $4.01 \pm 0.73$ & $\mathrm{C}_{15} \mathrm{H}_{24}$ \\
\hline$\alpha$-Humulene & 11.85 & 1,455 & $2.13 \pm 0.11$ & $\mathrm{C}_{15} \mathrm{H}_{24}$ \\
\hline Germacrene-D & 12.18 & 1,462 & $2.52 \pm 0.53$ & $\mathrm{C}_{15} \mathrm{H}_{24}$ \\
\hline Germacrene-B & 12.37 & 1,535 & $0.9 \pm 0.08$ & $\mathrm{C}_{15} \mathrm{H}_{24}$ \\
\hline Sesquiterpene hydrocarbons & & & 11.27 & \\
\hline Globulol & 13.48 & 1,590 & $1.67 \pm 0.16$ & $\mathrm{C}_{15} \mathrm{H}_{26} \mathrm{O}$ \\
\hline Viridiflorol & 13.61 & 1,591 & $9.9 \pm 0.67$ & $\mathrm{C}_{15} \mathrm{H}_{26} \mathrm{O}$ \\
\hline Oxygenated sesquiterpenes & & & 11.58 & \\
\hline Humulene epoxide & 13.78 & 1,606 & $0.86 \pm 0.02$ & $\mathrm{C}_{15} \mathrm{H}_{24} \mathrm{O}$ \\
\hline Oxygenated sesquiterpenoid & & & 0.86 & \\
\hline Total identified & 99.92 & & & \\
\hline
\end{tabular}

† Identification of components based on the GC-MS Wiley version 7.0 library and National Institute of Standards and Technology 05 MS (NIST) data library.

₹ Rl, retention index.

§ Percentages of the total of the essential oil (EO) from the leaves of S. officinalis are the means of 3 runs and were obtained from electronic integration measurements using a selective mass detector.

amount of carvone $(6.2 \%)$, $\beta$-thujone $(5.7 \%)$, and borneol $(2.2 \%)$. Among the sesquiterpene fraction $(22.85 \%)$, sesquiterpene hydrocarbons $(11.58 \%)$ were dominated by trans- $\beta$-caryophyllene (4.0\%) while viridiflorol (9.9\%) was recognized as the major constituent of the sesquiterpene oxygenated portion. This essential oil also showed a low-oxygenated sesquiterpenoid content of humulene epoxide $(0.86 \%)$. 


\section{Total phenolic and flavonoid contents of the essential oil from S. officinalis $L$.}

The phenolic content was $134.3 \pm 17.61 \mu \mathrm{g}$ GAE/mL. The flavonoid content was $119.5 \pm 18.75 \mu \mathrm{g} \mathrm{QE} / \mathrm{mL}$.

\section{Evaluation of the antioxidant activity of the essential oil from S. officinalis L.}

The essential oil had an antioxidant activity to scavenge DPPH free radicals with an $\mathrm{IC}_{50}=970 \pm 5.5 \mu \mathrm{g} / \mathrm{mL}$ (Figure 2).

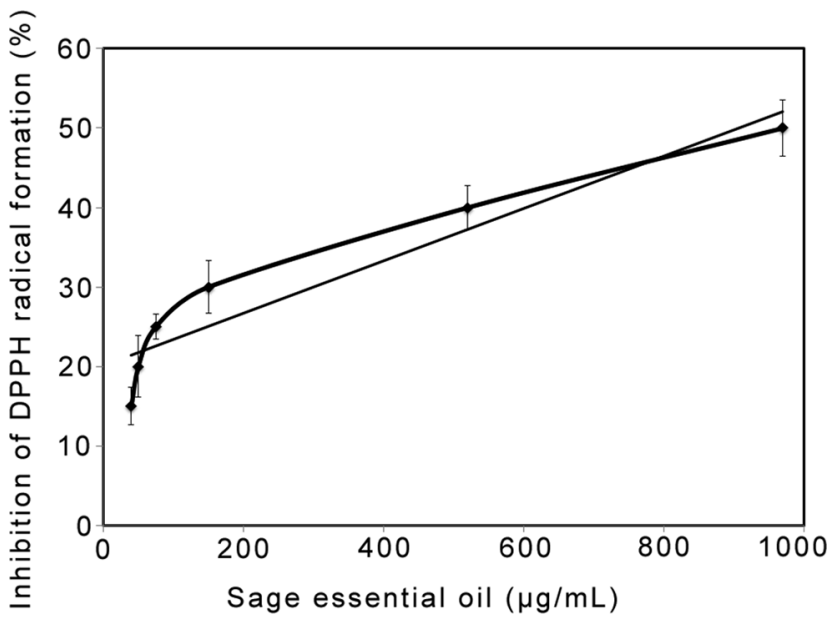

Figure 2. 2,2'-Diphenyl-1-picrylhydrazyl (DPPH) free radical scavenging activity (\% inhibition) of essential oil from the leaves of Salvia officinalis $\mathrm{L}$. in methanol. Absorbance was determined at $517 \mathrm{~nm}$. Means and standard deviations of triplicate measurements are presented. A regression line shows $y=0.033 x+17.99 ; R^{2}=0.898 . I C_{50}=970 \pm 5.5 \mu \mathrm{g} / \mathrm{mL}$. Error bars indicate standard deviation.

\section{Antibacterial activity of essential oil from S. officinalis L.}

The essential oil inhibits both gram-positive (E. faecalis, $M$. luteus, S. enterica, B. subtilis, and $S$. aureus) and gramnegative bacteria (E. coli, K. pneumoniae, A. tumefaciens, and $P$. aeruginosa) (Table 2). For gram-positive bacteria, the highest inhibition diameter $(24.8 \pm 0.11 \mathrm{~mm})$ was obtained for $B$. subtilis. This value was significantly higher $(P<0.001)$ than the lowest value $(9.5 \pm 0.47 \mathrm{~mm})$ obtained for $M$. luteus. For gram-negative bacteria, the essential oil was highly active against $E$. coli ATCC 8739 and slightly active against A. tumefaciens with significantly different inhibition diameters of $25.2 \pm 0.41 \mathrm{~mm}$ and $8.7 \pm 0.28 \mathrm{~mm}$, respectively. The MIC values of the essential oil ranged from $62.2 \pm 3.9 \mu \mathrm{g} /$ $\mathrm{mL}$ to $1398.1 \pm 50.7 \mu \mathrm{g} / \mathrm{mL}$ for gram-positive bacteria and from $323.4 \pm 69.5 \mu \mathrm{g} / \mathrm{mL}$ to $968.4 \pm 120.6 \mu \mathrm{g} / \mathrm{mL}$ for gramnegative bacteria. The lowest MIC (most potent activity) was observed against $B$. subtilis $(62.2 \pm 3.9 \mu \mathrm{g} / \mathrm{mL})$. The MBC values of essential oil ranged from $120.3 \pm 7.6 \mu \mathrm{g} / \mathrm{mL}$ to $1387.4 \pm 161.8 \mu \mathrm{g} / \mathrm{mL}$ for gram-positive bacteria and from $386 \pm 8.3 \mu \mathrm{g} / \mathrm{mL}$ to $1225.2 \pm 100.9 \mu \mathrm{g} / \mathrm{mL}$ gram-negative bacteria, respectively. The most potent activity $(386 \pm 8.3 \mu \mathrm{g} / \mathrm{mL})$ was observed against $E$. coli.

\section{Discussion}

The phytochemical characteristics of essential oil extracted from the leaves of the common sage $S$. officinalis L. collected from Abha (Saudi Arabia) are comparable to those reported in the literature $[10-17,28]$. Based on the comparative data

Table 2. Antibacterial activity of essential oil from Salvia officinalis L.

\begin{tabular}{|c|c|c|c|c|c|}
\hline \multirow[t]{2}{*}{ Gram staining } & \multirow[t]{2}{*}{ Bacteria } & \multicolumn{2}{|c|}{ Inhibition diameter (mm) } & \multirow[t]{2}{*}{$M I C \dagger(\mu \mathrm{g} / \mathrm{mL})$} & \multirow[t]{2}{*}{$M B C \neq(\mu \mathrm{g} / \mathrm{mL})$} \\
\hline & & EO & Gentamycin & & \\
\hline \multirow[t]{5}{*}{ Positive } & Enterococcus faecalis ATCC 29212 & $16.6 \pm 0.23$ & $17.4 \pm 0.95$ & $658.6 \pm 37.2$ & $869.6 \pm 95.8$ \\
\hline & Micrococcus luteus ATCC 4698 & $9.5 \pm 0.47$ & $19.8 \pm 0.89$ & $128.3 \pm 9.7$ & $121.2 \pm 8.1$ \\
\hline & Salmonella enterica ATCC 35664 & $14.2 \pm 0.51$ & $18.2 \pm 0.51$ & $1,398.1 \pm 50.7$ & $1,387.4 \pm 161.8$ \\
\hline & Bacillus subtilis ATCC 6633 & $24.8 \pm 0.11$ & $20.9 \pm 0.42$ & $62.2 \pm 3.9$ & $120.3 \pm 7.6$ \\
\hline & Streptococcus aureus ATCC 29213 & $23.5 \pm 0.57$ & $17.7 \pm 0.55$ & $123.5 \pm 5.7$ & $153 \pm 6.2$ \\
\hline \multirow[t]{5}{*}{ Negative } & Escherichia coli ATCC 8739 & $25.2 \pm 0.41$ & $21.1 \pm 0.25$ & $350.2 \pm 6.4$ & $386 \pm 8.3$ \\
\hline & Klebsiella pneumoniae ATCC 10031 & $22.6 \pm 0.73$ & $18.7 \pm 0.93$ & $450.3 \pm 56.6$ & $557.1 \pm 96.7$ \\
\hline & Shigella sonnei ATCC 29930 & $15.4 \pm 0.17$ & $18.2 \pm 0.63$ & $968.4 \pm 120.6$ & $995.2 \pm 145.6$ \\
\hline & Agrobacterium tumefaciens ATCC 23308 & $8.7 \pm 0.28$ & $19.1 \pm 0.31$ & $650.7 \pm 40.8$ & $1,225.2 \pm 100.9$ \\
\hline & Pseudomonas aeruginosa ATCC 9027 & $21.3 \pm 0.34$ & $18.2 \pm 0.54$ & $323.4 \pm 69.5$ & $394.8 \pm 86.8$ \\
\hline
\end{tabular}

EO, essential oil from the leaves of $S$. officinalis.

$+\mathrm{MIC}$, minimum inhibitory concentration.

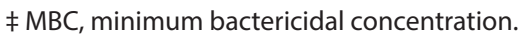

Values are presented as means of 3 measurements \pm standard deviation. 
Table 3. Comparative data for the regional chemical profiles of essential oils from the common sage Salvia officinalis.

\begin{tabular}{|c|c|c|c|c|c|c|c|c|}
\hline Chemical class and components & $\begin{array}{l}\text { Abha (Saudi Arabia) } \\
\text { [present work] }\end{array}$ & $\begin{array}{c}\text { Tunisia } \\
\text { [10] }\end{array}$ & $\begin{array}{c}\text { Greece } \\
\text { [11] }\end{array}$ & $\begin{array}{c}\text { Algeria } \\
\text { [12] }\end{array}$ & $\begin{array}{c}\text { Serbia and } \\
\text { Montenegro [13] }\end{array}$ & $\begin{array}{l}\text { Iran } \\
{[14]}\end{array}$ & $\begin{array}{c}\text { Kashmir } \\
\text { [15] }\end{array}$ & $\begin{array}{c}\text { Turkey } \\
{[16]}\end{array}$ \\
\hline \multicolumn{9}{|l|}{ Monoterpene hydrocarbons } \\
\hline$\alpha$-Pinene & $1.15 \pm 0.1$ & 1.95 & 3.3 & 0.22 & 4.58 & 3.5 & 7.69 & 3.02 \\
\hline Camphene & $2.58 \pm 0.17$ & 0.98 & 1.31 & 0.41 & 5.28 & 0.25 & 6.11 & 0.6 \\
\hline$\beta$-Pinene & $2.06 \pm 0.05$ & 5.11 & - & 0.37 & 1.69 & 0.25 & 28.33 & 13.08 \\
\hline Myrcene & $1.26 \pm 0.11$ & 2.04 & 0.4 & 0.25 & 0.75 & - & - & 1.02 \\
\hline$\alpha$-Terpinene & $0.32 \pm 0.03$ & 0.41 & 0.19 & - & 0.34 & - & 0.26 & 0.27 \\
\hline$p$-Cymene & $0.36 \pm 0.02$ & 0.35 & 0.32 & - & 1.89 & - & 1.19 & - \\
\hline$\gamma$-Terpinene & $0.59 \pm 0.05$ & 0.83 & 0.27 & - & 0.59 & - & 0.66 & - \\
\hline$\alpha$-Terpinolene & $0.53 \pm 0.04$ & 0.28 & 0.58 & - & 0.38 & - & 0.46 & - \\
\hline \multicolumn{9}{|l|}{ Monoterpenes, oxygenated } \\
\hline 1,8-Cineole & $15.0 \pm 0.51$ & 19.98 & 41.2 & 22.97 & 18.54 & 7.5 & 7.76 & - \\
\hline$\alpha$-Thujone & $14.9 \pm 0.35$ & 18.35 & 7.2 & 36.74 & 25.35 & - & 40.45 & 4.68 \\
\hline$\beta$-Thujone & $5.68 \pm 0.27$ & 7.1 & 5.58 & 8.81 & 6.04 & - & 4.97 & 31.9 \\
\hline Camphor & $20.3 \pm 0.91$ & 7.23 & 25.3 & 11.34 & 24.8 & - & 36.97 & - \\
\hline Pinocamphone & $0.38 \pm 0.03$ & 0.55 & - & - & 0.34 & 1.8 & - & - \\
\hline Borneol & $2.16 \pm 0.14$ & 1.2 & 3.73 & 2.94 & 8.5 & 1.6 & 18.38 & 3.14 \\
\hline$\alpha$-Terpineol & $1.15 \pm 0.06$ & 0.79 & 0.14 & 0.25 & 0.22 & 3.8 & 0.5 & - \\
\hline Carvone & $6.2 \pm 0.15$ & - & - & - & - & - & - & - \\
\hline Bornyl acetate & $1.6 \pm 0.07$ & 0.25 & 1.8 & - & 4.91 & 0.12 & 2.1 & - \\
\hline \multicolumn{9}{|l|}{ Sesquiterpene hydrocarbons } \\
\hline$\beta$-Bourbonene & $0.89 \pm 0.03$ & 0.03 & - & - & - & - & - & - \\
\hline$\beta$-Elemene & $0.82 \pm 0.03$ & 0.03 & - & - & - & - & - & - \\
\hline trans- $\beta$-Caryophyllene & $4.01 \pm 0.73$ & 6.48 & 4.48 & 1.54 & - & 11.5 & 17.32 & 3.08 \\
\hline$\alpha$-Humulene & $2.13 \pm 0.11$ & 6.27 & 2.56 & 3.15 & 12.49 & - & 3.6 & 10.17 \\
\hline Germacrene D & $2.52 \pm 0.53$ & 0.02 & - & - & - & 2.7 & 0.42 & - \\
\hline Germacrene B & $0.9 \pm 0.08$ & - & - & - & - & - & - & - \\
\hline \multicolumn{9}{|l|}{ Sesquiterpenes, oxygenated } \\
\hline Globulol & $1.67 \pm 0.16$ & 0.12 & - & - & - & 0.74 & - & - \\
\hline Viridiflorol & $9.9 \pm 0.67$ & 16.32 & 2.61 & - & 26.1 & - & 2.16 & 10.74 \\
\hline \multicolumn{9}{|l|}{ Sesquiterpenoid, oxygenated } \\
\hline Humulene epoxide & $0.86 \pm 0.02$ & 0.85 & 1.8 & - & 1.82 & - & 1.06 & - \\
\hline
\end{tabular}

(Table 3), the chemical profile of the essential oil is generally similar to that reported in the literature. The essential oil is dominated by the oxygenated monoterpenoids representing $67.36 \%$, which is slightly different from values reported for samples from other countries [11-17, 28]. For example, the oil from samples collected from Tunisia showed mainly 1,8cineole, $\alpha$-thujone, $\beta$-thujone, borneol, $\beta$-elemene, camphor, and $\alpha$-pinene [10]. However, leaf essential oil contents from S. officinalis collected from Serbia showed mainly $\alpha$-thujone, viridiflorol, camphor, 1,8-cineole, $\alpha$-humulene, trans- $\beta$ caryophyllene, borneol, and $\alpha$-pinene [13]. Generally, the yield and the chemical composition of $S$. officinalis essential oil depend on various factors (including genetic background, region, environmental conditions, season, plant parts used for essential oil extraction, and the extraction method) as reported by other investigators [16, 29-31]. The proportion of oxygenated monoterpenes, such as camphor, 1,8-cineole, $\alpha$-thujone, and $\beta$-thujone, is considered to indicate the quality of the extracted oil. According to the literature, good quality oil from S. officinalis should contain $>50 \%$ of $\alpha$-thujone and $\beta$-thujone and $<20 \%$ of camphor [2]. Several constituents ( $\alpha$-pinene, camphene, limonene, 1,8-cineole, linalool and its esters, cis-thujone ((+)- $\beta$-thujone), trans-thujone ((-)- $\alpha$-thujone), camphor, bornyl acetate, and $\alpha$-humulene) are standardized 
in the essential oils of $S$. officinalis L. for its medicinal use according to ISO 9909 [32]. Following the ISO 9909, standards are cis-thujone (18\%-43\%), camphor $(4.5 \%-24.5 \%)$, cineole $(5.5 \%-13 \%)$, humulene $(0 \%-12 \%)$, trans-thujone (3\%-8.5\%), camphene $(1.5 \%-7 \%)$, pinene $(1 \%-6.5 \%)$, limonene $(0.5 \%-3 \%)$, bornyl acetate (maximum $2.5 \%$ ), and linalool (maximum 1\%) [32]. In the present study, the extracted oil contains a considerable percentage of carvone (6.2\%), useful as a natural inhibitor of sprouting in many preserved vegetables [32, 33]. Moreover, carvone can be used to inhibit seed germination [34, 35] and as an insecticide [36]. The major compound classes of essential oil from leaves of S. officinalis were alkanes with $\mathrm{C} 10-\mathrm{C} 15$ chain lengths.

Based on the biochemical analysis, phenolic and flavonoid components in sage were found as reported by other investigators [17,37]. However, it is important to highlight the variability of total phenolic and flavonoid components found by other studies, which is related to the location, the harvesting season, parts of sage, and the solvent used for the extraction [38]. For example, the total phenolic content ranged from $98.84 \mathrm{mg} \mathrm{GAE} / \mathrm{g}$ in extracts of $S$. officinalis collected from Pleš (Eastern Serbia) and $96.36 \mathrm{mg} \mathrm{GAE} / \mathrm{g}$ in extracts of $S$. officinalis collected from Luštica (Montenegro) and the total flavonoids content ranged from $31.75 \mathrm{mg} \mathrm{QE} / \mathrm{g}$ in extracts of S. officinalis collected from Pleš (Eastern Serbia) and $29.3 \mathrm{mg}$ $\mathrm{QE} / \mathrm{g}$ in extracts of $S$. officinalis collected from Luštica (Montenegro) [37]. However, methanol extracts of S. officinalis showed a total phenolic content ranging from $63.9 \mathrm{mg} \mathrm{GAE} / \mathrm{g}$ to $134.4 \mathrm{mg} \mathrm{GAE} / \mathrm{g}$ [38]. Generally, flavonoids and phenolics are present in large amounts in plant extracts $[1,3,23]$.

Essential oils from $S$. officinalis have been considered as potential sources of bioactive compounds. In the second part of the present study, our research focused on the determination of the antioxidant and the antimicrobial activities of the extracted essential oil. The essential oil showed an antioxidant capacity. This capacity of essential oil from S. officinalis has already been found in studies of the essential oil from other locations. For example, the essential oil of the Tunisian S. officinalis showed an $\mathrm{IC}_{50}$ of $6.7 \mathrm{mg} / \mathrm{mL}$ [39]. Two commercial samples of dry leaves of $S$. officinalis from Poland presented a range of DPPH activities with inhibition of $60.9 \pm 2.9 \%$ and $41.5 \pm 3.1 \%$ [38]. An $\mathrm{IC}_{50}$ of $28.28 \pm 10.241$ was reported for extracts of $S$. officinalis from Pleš (Eastern Serbia) and an $\mathrm{IC}_{50} 48.62 \pm 29.181$ was reported for extracts from Luštica (Montenegro) [37]. The observed antiradical activity of $S$. officinalis is probably related to monoterpenes, like $\alpha$-pinene, which is recognized for its powerful antioxidant activity [40] and to its high sesquiterpene content $[39,41]$. The contribution of major and minor compounds in the antiradical activity may be synergistic and not related to one or more active biomolecules alone [40]. The observed antioxidant activities may also be related to the presence of high quantities of flavonoid and phenolic compounds in the extract.

Our present findings confirm the antibacterial activity of essential oil from sage as reported in the literature [39]. That A. tumefaciens showed the smallest diameter of inhibition suggests the lower sensitivity of gram-negative bacteria compared with gram-positive bacteria as reported by other investigators [39]. The maximum activity was observed against $B$. subtilis as consistent with the literature [39]. The antibacterial activities of essential oil of $S$. officinalis are related to its chemical composition $[42,43]$ and are generally higher than those reported for other plants such as Thuja occidentalis [27]. From this perspective, the antibacterial activities of essential oil from sage are considered to be linked with some specific compounds in the oil including camphor, $\alpha$-thujone, 1,8-cineole, and $\alpha$-pinene. These compounds are known for their antimicrobial activity against a large spectrum of microorganisms [44]. Moreover, phenolic compounds contribute effectively to antibacterial activities as found by others [43]. The results obtained support the use of this natural product in various fields such as food preservation and disease treatment [30]. The variability of the chemical composition of essential oils of S. officinalis, depending on various factors (including genetic background, region, environmental conditions, season, plant parts used for essential oil extraction, the extraction method) [16, 29-31], affects its antimicrobial activity.

A limitation of the present work is that only a single method was used to determine antioxidant activity. Measurement of antioxidant content is not straightforward, as antioxidants collectively are a diverse group of compounds with different reactivities toward various reactive oxygen species. To gain a better determination more than one method is necessary [45], other methods include the oxygen radical absorbance capacity (ORAC), the 6-hydroxy-2,5,7,8-tetramethylchroman-2-carboxylic acid (Trolox) equivalent antioxidant capacity assay, usually combined with 2,2'-azino-bis(3-ethylbenzothiazoline-6-sulfonic acid) (ABTS) decolorization, and ferric reducing antioxidant power (FRAP), although any relationship between antioxidant values and a health benefit has not been established [46].

Even though most of the compounds found in the essential oil are well known, unequivocal identification can be difficult, despite modern retention time/mass spectrometry/computer searching algorithms, and differences in nomenclature exist leading to misidentifications. The situation with ringed, heterocyclic, and isomeric compounds is sometimes complicated. Overloaded spectra and other problems with the gas chromatography or mass spectrometer can severely affect results, and occasionally library searches do not pick up subtle differences. Retention times may vary as columns age and if different 
carrier gases are used. We did not use internal standards, such as octane, but noted the retention times of easily identified major peaks. Nevertheless, unequivocal identification requires the use of authentic reference standards [19], which were not used in the present study.

\section{Conclusion}

Our findings for composition and antibacterial and antioxidant activities are generally consistent with those for essential oils of $S$. officinalis L. collected at other locations as reported in the literature. Any variability in the essential oil composition or activity can be explained by factors including location, altitude, terroir, plant part and developmental stage, and extraction methods. Our data provide the composition of essential oil from leaves of $S$. officinalis L. collected at Abha and may be helpful for the future development of antibacterial and antioxidant agents.

Author contributions. All authors contributed substantially to the conception and design of the study. AEJ acquired the data and AEJ, MH, MKAM, and FBR analyzed and interpreted it. AEJ drafted the manuscript and all authors critically revised it. All the authors approved the final version submitted for publication and take responsibility for the statements made in the published article.

Acknowledgments. This work was supported by the King Khalid University, Abha, Saudi Arabia (by grant R.G.P. $1 / 144 / 40)$. We express our gratitude to the Deanship of Scientific Research, King Khalid University, for its support of this study.

Conflicts of interest statement. The authors have each completed and submitted an International Committee of Medical Journal Editors Form for Disclosure of Potential Conflicts of Interest. None of the authors has any potential or actual conflict of interest to disclose in relation to the present study.

Data sharing statement. The data sets generated or analyzed during the present study are available from the corresponding author on reasonable request.

\section{References}

[1] Che CT, Zhang H. Plant natural products for human health. Int J Mol Sci. 2019; 20:830. doi: 10.3390/ijms20040830
[2] Guenther E. The essential oils. New York: D. Van Nostrand Company; 1948.

[3] Raja RR. Medicinally potential plants of Labiatae (Lamiaceae) family: an overview. Res J Med Plant. 2012; 6:203-13.

[4] Baricevic D, Sosa S, Della Loggia R, Tubaro A, Simonovska B, Krasna A, Zupancic A. Topical anti-inflammatory activity of Salvia officinalis L. leaves: the relevance of ursolic acid. J Ethnopharmacol. 2001; 75:125-32.

[5] Cuvelier M-E, Berset C, Richard H. Antioxidant constituents in sage (Salvia officinalis). J Agric Food Chem. 1994; 42:665-69.

[6] Akhondzadeh S, Noroozian M, Mohammadi M, Ohadinia S, Jamshidi AH, Khani M. Salvia officinalis extract in the treatment of patients with mild to moderate Alzheimer's disease: a double blind randomized and placebo-controlled trial. J Clin Pharm Ther. 2003; 28:53-9.

[7] Dhifi W, Bellili S, Jazi S, Bahloul N, Mnif W. Essential oils' chemical characterization and investigation of some biological activities: a critical review. Medicines (Basel). 2016; 3:25. doi: 10.3390/ medicines3040025

[8] Catione P, Marotti M, Toderi G, Tétényi P. Coltivazione delle plante medicinali e aromatiche [Cultivation of medicinal and aromatic plants]. Bologna: Pàtron Editore; 1986, p. 253-63. [in Italian]

[9] Beier RC. Natural pesticides and bioactive components in foods. In: Ware GW, editor. Nigg HN, Bevenue A, coordinating editors. Reviews of environmental contamination and toxicology. New York: Springer; 1990, p. 47-137. de Voogt P, series editor. RECT (continuation of Residue Rev), vol. 113.

[10] Farhat MB, Jordán MJ, Chaouch-Hamada R, Landoulsi A, Sotomayor JA. Phenophase effects on sage (Salvia officinalis L.) yield and composition of essential oil. JARMAP. 2016; 3:87-93.

[11] Hassiotis CN. The role of aromatic Salvia officinalis L. on the development of two mycorrhizal fungi. Biochem Systemat Ecol. 2018; 77:61-7.

[12] Benkherara S, Bordjiba O, Djahra AB. Évaluation in vitro de l'activité antibactérienne de l'huile essentielle de Salvia officinalis. [In vitro evaluation of the antibacterial activity of essential oil of Salvia officinalis]. Phytothérapie. 2015; 13:14-8. [in French, English abstract]

[13] Couladis M, Tzakou O, Mimica-Dukić N, Jančić R, Stojanović D. Essential oil of Salvia officinalis L. from Serbia and Montenegro. Flavour Fragr J. 2002; 17:119-26.

[14] Hosseini MM, Akbarzadeh A, Flaminic G. Profiling of compositions of essential oils and volatiles of Salvia limbata using traditional and advanced techniques and evaluation for biological activities of their extracts. Chem Biodiversity. 2017; 14:e1600361. doi: 10.1002/ cbdv.201600361

[15] Bhat G, Rasool S, Shakeel-u-Rehman, Ganaie M, Qazi PH, Shawl AS. Seasonal variation in chemical composition, antibacterial and antioxidant activities of the essential oil of leaves of Salvia officinalis (sage) from Kashmir, India. TEOP. 2016; 19:1129-40.

[16] Rezaeieh KAP, Gurbuz B. Volatile oil yield and constituents of Salvia officinalis, S. tomentosa Mill. and S. glutinosa growing in Ankara, Turkey. Asian J Agric Res. 2017; 11:43-47.

[17] Generalić I, Skroza D, Ljubenkov I, Katalinić A, Burčul F, Katalinić V. Influence of the phenophase on the phenolic profile and antioxidant properties of Dalmatian sage. Food Chem. 2011; 127:427-33. 
[18] Ben Hsouna A, Dhibi S, Dhifi W, Ben Saad R, Brini F, Hfaidh N, Mnif W. Essential oil from halophyte Lobularia maritima: protective effects against $\mathrm{CCl}_{4}$-induced hepatic oxidative damage in rats and inhibition of the production of proinflammatory gene expression by lipopolysaccharide-stimulated RAW 264.7 macrophages. RSC Adv. 2019; 9:36758-70.

[19] Adams RP. Identification of essential oil components by gas chromatography/mass spectrometry. 4th ed. Carol Stream, IL: Allured Publishing; 2009.

[20] Slinkard K, Singleton V. Total phenol analysis: automation and comparison with manual methods. Am J Enol Vitic. 1977; 28:49-55.

[21] Zhishen J, Mengcheng T, Jianming W. The determination of flavonoid contents in mulberry and their scavenging effects on superoxide radicals. Food Chem. 1999; 64:555-9.

[22] Hatano T, Kagawa H, Yasuhara T, Okuda T. Two new flavonoids and other constituents in licorice root: their relative astringency and radical scavenging effect. Chem Pharm Bull (Tokyo). 1988; 36:2090-7.

[23] Mensor LL, Menezes FS, Leitão GG, Reis AS, dos Santos TC, Coube CS, Leitão SG. Screening of Brazilian plant extracts for antioxidant activity by the use of DPPH free radical method. Phytother Res. 2001; 15:127-30.

[24] Shimada K., Fujikawa K., Yahara K., Nakamura T. Antioxidative properties of xanthan on the auto oxidation of soybean in cyclodextrin emulsion. J Agri Food Chem. 1992; 40:945-8.

[25] Travers RS, Martin PAW, Reichelderfer CF. Selective process for efficient isolation of soil Bacillus spp. Appl Environ Microbiol. 1987; 53:1263-6

[26] Ghazghazi H, Chedia A, Weslati M, Trakhna F, Houssine S, Abderrazak M, Brahim $\mathrm{H}$. Chemical composition and in vitro antimicrobial activities of Mentha pulegium leaves extracts against foodborne pathogens. J. Food Saf. 2013; 33:239-46.

[27] Bellili S, Aouadhi C, Dhifi W, Ghazghazi H, Jlassi C, Sadaka C, et al. The influence of organs on biochemical properties of Tunisian Thuja occidentalis essential oils. Symmetry. 2018; 10:649. doi: 10.3390/sym10110649

[28] Fellah S, Romdhane M, Abderraba M. Extraction et étude des huiles essentielles de la Salvia officinalis. $L$ cueillie dans deux régions différentes de la Tunisie [Extraction and a study of essential oils of Salvia officinalis from two different regions in Tunisia]. J Soc Alger Chim. 2006; 16:193-202. [in French, abstracts in English and Arabic]

[29] Bernotiené G, Nivinskiené O, Butkiené R, Mockuté D. Essential oil composition variability in sage (Salvia officinalis L.). Chemija. 2007; 18:38-43.

[30] de Hadri A, del Rio MG, Sanz J, Coloma AG, Idaomar M, Ozanas BR. Cytotoxic activity of $\alpha$-humulene and transcaryophyllene from Salvia officinalis in animal and human tumor cells. An R Acad Nac Farm. 2010; 76:343-56. [in English, Spanish abstract]

[31] Santos-Gomes PC, Fernandes-Ferreira M. Organ and seasondependent variation in the essential oil composition of Salvia officinalis L. cultivated in two different sites. J Agri Food Chem. 2001; 49:2908-16

[32] Bruneton J. Pharmacognosy: phytochemistry, medicinal plants. 2nd ed. London: Intercept; 1999.
[33] Raal A, Orav A, Arak E. Composition of the essential oil of Salvia officinalis L. from various European countries. Nat Prod Res. 2007; 21:406-11.

[34] Bouwmeester HJ, Gershenzon J, Konings MCJM, Croteau R. Biosynthesis of the monoterpenes limonene and carvone in the fruit of caraway. I. Demonstration of enzyme activities and their changes with development. Plant Physiol. 1998; 117:901-12.

[35] Toxopeus H, Bouwmeester HJ. Improvement of caraway essential oil and carvone production in The Netherlands. Ind Crop Prod. 1992; 1:295-01.

[36] Vejražka K, Hrudová E, Kocourková B, Cerkal R. UDC 632.911. Insecticidal effect of carvone against the wheat weevil (Sitophiius granarius L.). In: Ugarčić-Hardi Ž, editor. Proceedings of the 4th International Congress on Flour-Bread ' 07 and 6th Croatian Congress of Cereal Technologists; 2007 October 24-27, Opatija, Croatia. Osijek, Croatia: Faculty of Food Technology, University of Josip Juraj Strossmayer. 2008; p. 261-65.

[37] Duletić-Laušević S, Alimpić-Adraski A, Pavlović D, Marin PD, Lakušić D. Salvia officinalis of different origins: antioxidant activity, phenolic and flavonoid content of extracts. Agro Food Industry Hi-tech. 2016; 27:52-55.

[38] Jasicka-Misiak I, Poliwoda A, Petecka M, Buslovych O, Shlyapnikov VA, Wieczorek PP. Antioxidant phenolic compounds in Salvia officinalis L. and Salvia sclarea L. Ecol Chem Eng S. 2018; 25:133-42.

[39] Ben Khedher MR, Ben Khedher S, Chaieb I, Tounsi S, Hammami M. Chemical composition and biological activities of Salvia officinalis essential oil from Tunisia. EXCLI J. 2017; 16:160-73.

[40] Wang W, Wu N, Zu YG, Fu YJ. Antioxidative activity of Rosmarinus officinalis L. essential oil compared to its main components. Food Chem. 2008; 108:1019-22.

[41] Tamil Selvi M., Thirugnanasampandan R., Sundarammal S. Antioxidant and cytotoxic activities of essential oil of Ocimum canum Sims. from India. J Saudi Chem Soc. 2015; 19:97-100.

[42] Canillac N, Mourey A. Antibacterial activity of the essential oil of Picea excelsa on Listeria, Staphylococcus aureus and coliform bacteria. Food Microbiol. 2001; 18:261-8.

[43] Dorman HJD, Deans SG. Antimicrobial agents from plants: antibacterial activity of plant volatile oils. J Appl Microbiol. 2000; 88:308-16.

[44] Sökmen A, Vardar-Ünlü G, Polissiou M, Daferera D, Sökmen M, Dönmez E. Antimicrobial activity of essential oils and methanol extracts of Achillea sintenisii Hub Mor. (Asteraceae). Phytother Res. 2003; 17:1005-10.

[45] Ou B, Huang D, Hampsch-Woodill M, Flanagan JA, Deemer EK. Analysis of antioxidant activities of common vegetables employing oxygen radical absorbance capacity (ORAC) and ferric reducing antioxidant power (FRAP) assays: a comparative study. J Agric Food Chem. 2002; 50:3122-8.

[46] Chun O, Frei B, Gardner C, Alekel DL, Killen JJ Jr. Antioxidants: in depth [Internet]. Bethesda, MD: National Center for Complementary and Integrative Health (NCCIH), National Institutes of Health, U.S. Department of Health \& Human Services; 2013 [cited 2020 November 07]. Available from: https://www.nccih.nih gov/health/antioxidants-in-depth 